\title{
Mean intrasellar pressure, visual field, headache intensity and quality of life of patients with pituitary adenoma
}

\author{
Aldo Pereira-Neto', André Meireles Borba', \\ Paulo Andrade de Mello', Luciana Ansanelli Naves², \\ Antônio Santos de Araújo Jr¹, Luis Augusto Casulari²
}

\begin{abstract}
Intrasellar pressure (ISP) measurement technique has recently opened a new line of research in neuroendocrinology. The absolute and mean ISP values were investigated in 25 patients consecutively operated at the Brasilia University Hospital (DF). These data were correlated with serum prolactin levels, number of visual quadrant affected, tumor size, quality of life (measured through the SF-36 scale) and graded headache (measured through the HIT-6 scale). No correlation was observed. The $p$ values were $0.887 ; 0.137 ; 0.892 ; 0.812$ and 0.884 ; respectively. The HIT-6 values were inversely and moderately correlated with total RAND SF-36 and its mental and physical dimensions.
\end{abstract}

Key words: pituitary adenoma, intrasellar pressure, headache.

Pressão intra-selar média, campo visual, intensidade de cefaléia e qualidade de vida em portadores de adenoma hipofisário

\section{RESUMO}

A técnica da medida da pressão intra-selar (PIS) abriu, recentemente, uma nova linha de pesquisa em neuroendocrinologia. O objetivo deste estudo foi aferir os valores absolutos da PIS e calcular a pressão intra-selar média (PIM) em uma população de 25 pacientes operados consecutivamente no Hospital Universitário de Brasília (DF). Não se observou correlação significativa entre a PIM e o número de quadrantes visuais comprometidos $(p=0,137)$, área do tumor $(p=0,892)$, nível de qualidade de vida mensurado pela escala SF-36 $(p=0,812)$ e a presença e a intensidade da cefaléia mensurada pela escala HIT-6 $(p=0,884)$. Contudo, o HIT-6 correlacionou-se de forma inversa e intensidade moderada com os valores de HIT-6 e suas dimensões mental e física.

Palavras-chave: adenoma hipofisário, pressão intraselar, cefaléia.

Pituitary adenomas are benign and frequent neoplasms, accounting for $10-14 \%$ of all intracranial tumors ${ }^{1}$. They manifest clinically through syndromes of hyper or hypo hormone secretion associated or not to the compression of peri-sellar structures. Their blood is supplied mainly by vessels in a portal system in the pituitary stalk, although there are evidences that under special conditions an additional arterial supply occurs ${ }^{2}$. The interruption of the flow determines the suspension on the hypothalamic control on the anteri- or pituitary gland, which explains the hypopituitarism and hyperprolactinemia observed in several patients with macroadenomas ${ }^{3}$. Also, the growth of a tumor inside the confined rigid limits of the sella turcica increases the intrasellar pressure (ISP), an additional factor for ischemia and necrosis within the gland $\mathrm{d}^{4}$.

The presence of headache in patients with pituitary adenoma has always been explained by the distension of structures close to the sella, particularly the duramater. That does not account for the pain 
in all cases, as with patients with microadenomas, for example $^{5}$. The headache and the hormonal disturbance are among the factors that contribute to worsen the quality of life in a large number of patients ${ }^{6}$. The relationship between increased ISP, visual changes and headache was object of studies in recent years ${ }^{4,7-15}$, including in Brazil ${ }^{16}$. However, none of these evaluations used scales for assessing the quality of life and severity of headache in patients with pituitary adenomas.

This study measured ISP in 25 consecutive patients operated at the Brasília University Hospital - DF (HUB) from August 2002 to July 2004. The ISP values were studied according to the lesion area, number of visual quadrant affected, quality of life presence and severity of headaches.

\section{METHOD}

The inclusion criteria were: origin at the same Institution (Brasília University Hospital - HUB); conjoint assessment by endocrinology and neurosurgery teams, diagnostic confirmation, severity of illness and the secretory profile of the tumor was assessed by clinical, laboratorial and radiological exams (sella turcica CT scan) in addition to visual campimetry. It should be the primary transphenoidal adenomectomy and it was followed by histopathological confirmation of the diagnosis.

The number of visual quadrant affected was defined through preoperative visual campimetry using the same appliance to all patients: Humprhey System - HFA II 7301163-A12.3, Chaatawapha, MI, USA).

The headache severity was assessed by the Headache Impact Test scale (HIT-6) ${ }^{17}$. The quality of life was evaluated with the Research and Development Short Form Health Survey (RAND SF-36) ${ }^{18}$, both by means of the total score and by its mental and physical dimensions. Both evaluations were performed during the hospitalization period.

The anesthetic procedure was carefully taken as to avoid interference in the intracranial pressure that could impact on the ISP. All patients were operated and monitored by the same team. In cases of macroadenomas, the floor of the sella turcica and the dura were minimally opened $(2 \times 1 \mathrm{~mm})$. The fiberoptic catheter was introduced for $2 \mathrm{~mm}$ through the opening. When in microadenomas, the fenestration of the sella turcica was performed right at the site of lesion, based on image exams, although its borders could be minimally extended to obtain better identification of the tumor area. Prior to the measurement, a 60 seconds period was given as to ensure that the pressure wave stabilized. The fiberoptic tip then remained in the tumor for the next ten minutes. During this interval, ISP values were recorded every 20 seconds. At three, six and nine minutes, a Valsalva maneuver was performed for a period of five seconds. The mean intrasellar pressure corresponded to the average 30 values re- corded for each patient. After the measurement and establishment of the mean intrasellar pressure, surgery followed the usual planning, with the removal of the lesion and closure by plans.

The project was approved by the Ethics Committee of the Medical School of the University of Brasília (CEP/ FM-028/02) according to the ethical standards for scientific research involving humans. A post-informed consent form in accessible language explaining the procedure was signed prior to surgery. The normality distribution analysis was verified by the Kolmogorov-Smirnov test. Pearson correlation $(r)$, Spearman correlation $\left(r_{s}\right)$, analysis of variance (ANOVA) and Student $t$ tests were used. The data were processed with the software Statistical Package for the Social Sciences - SPSS 13.0 (SPSS Inc., Chicago, IL, USA) and $\mathrm{p}$ was considered significant if less than 0.05 , always in bicaudal analyses. Averages are presented as mean \pm standard deviation (SD).

\section{RESULTS}

Twenty-eight patients with pituitary adenoma were operated from August 2002 to July 2004 at the Brasília University Hospital (DF). Three patients were excluded due to reoperation, while 25 met the inclusion criteria. Ten patients (60\%) were female and fifteen (40\%) were male. The mean age was $36.4 \pm 14.7$ years. Sixteen patients had non-secreting adenomas (64\%), five had Cushing's disease (20\%) and four had acromegaly (16\%). The size of the tumors ranged from 0.1 and $25.4 \mathrm{~cm}^{2}$, with average of $5 \pm 5.8 \mathrm{~cm}^{2}$. Eight (32\%) lesions were microadenomas and 12 (48\%) had extrasellar extension of the lesion. The average ISP of all cases was $33.3 \pm 12.1 \mathrm{mmHg}$, ranging from 13.9 to $67.1 \mathrm{mmHg}$ (Table 1). The average ISP value was $81 \pm 9 \mathrm{mmHg}$.

Fifteen patients (60\%) had changes in the visual field: one patient had changes in three quadrants, three patients had four quadrants affected, one patient had five and another had six, three in seven and, finally, six patients had changes in all the eight quadrants. On average, $3.8 \pm 3.5$ visual quadrants per patient were found affected. From the ten patients with no visual field changes, four had macroadenomas.

The questionnaire for assessing quality of life RAND SF-36 showed values from 16 to 91 (average of 53 \pm 21.4 ). The assessment of the mental factors through RAND SF-

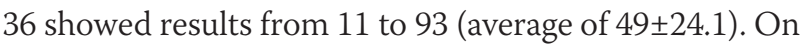
the other hand, the physical dimension through RAND SF-36 ranged from 16 to 95 (average of $53 \pm 21.7$ ).

The values for the HIT-6 questionnaire (Headache Impact Test) ranged from 36 to 75 (average of 57 points). Fourteen cases (56\%) scored for intense impact (60 or more points), two (8\%) for substantial impact (56 to 59 points), one (4\%) for moderate impact (50 to 55 points) 
Table 1. Age, number of visual quadrant affected, mean intrasellar pressure, tumor area and RAND SF36 (total, mental and physical) and HIT-6 scores, $n=25$.

\begin{tabular}{lccc}
\hline Variable & Mean \pm SD & Minimum & Maximum \\
\hline Age (years) & $36.4 \pm 14.7$ & 16 & 73 \\
Number of visual quadrant affected & $3.8 \pm 3.5$ & 0 & 8 \\
Mean ISP $(\mathrm{mmHg})$ & $33.3 \pm 12.1$ & 13.9 & 67.1 \\
Tumor area $\left(\mathrm{cm}^{2}\right)$ & $5.0 \pm 5.8$ & 0.1 & 25.4 \\
Total RAND SF-36 & $53 \pm 21.4$ & 16 & 91 \\
Mental RAND SF-36 & $52 \pm 22.9$ & 11 & 88 \\
Physical RAND SF-36 & $51 \pm 21.2$ & 15 & 91 \\
HIT-6 & $57 \pm 12.3$ & 36 & 75 \\
\hline
\end{tabular}

HIT-6: Headache Impact Test; RAND SF-36: Research and Development Short Form Health Survey, SD: Standard Deviation.

Table 2. Correlations between intrasellar pressure and the number of visual quadrant affected, tumor area, RAND SF-36 (total, mental and physical) and HIT-6 scores, $\mathrm{n}=25$.

\begin{tabular}{lcc}
\hline \multirow{2}{*}{ Variable } & \multicolumn{2}{c}{ Correlation with ISP } \\
\cline { 2 - 3 } Number of visual quadrant affected & $\mathrm{r}$ or $\mathrm{r}_{\mathrm{s}}$ & $\mathrm{p}$ \\
\hline Tumor area $\left(\mathrm{cm}^{2}\right)$ & $0.355^{\mathrm{S}}$ & 0.08 \\
Total RAND SF-36 & $0.081^{\mathrm{S}}$ & 0.70 \\
Mental RAND SF-36 & $-0.050^{\mathrm{p}}$ & 0.81 \\
Physical RAND SF-36 & $-0.027^{\mathrm{P}}$ & 0.90 \\
HIT-6 & $-0.066^{\mathrm{P}}$ & 0.75 \\
\hline
\end{tabular}

HIT-6: Headache Impact Test; RAND SF-36: Research and Development Short Form Health Survey; PPearson correlation, $r_{;}$'Spearman's rank correlation, $r_{s}$.

and for eight patients (32\%) the headache produced slight impact ( 49 points or less) in their lives.

In Table 2 are shown correlations among ISP and the number of visual quadrant affected, tumor area, RAND SF-36 (total, mental, and physical), and HIT-6 scores. The normality distribution was found in all variables, except for the "area of the tumor" and the "number of visual quadrant affected", in which the nonparametric test was applied (Table 2). No analysis reached significance power $(\mathrm{p}<0.05)$. The highest and nearest correlation about to reject the null hypothesis was found between ISP and the number of visual quadrant affected $\left(\mathrm{r}_{\mathrm{s}=} 0.355, \mathrm{p}=0.08\right)$.

Stratification according to the severity of headache impact (HIT-6) showed no significant difference in their respective mean ISP values. There is no value for normality of the RAND SF-36 scale with which the studied population could have been stratified as normal, abnormal or any other degrees, nevertheless, by dividing those patients into groups according to quartiles or percentiles no significant difference was found among them. Even the comparison of the mean ISP between these subgroups $(\mathrm{p}<0.05)$ was not significant (data not presented).

The analysis of possible differences in quality of life (RAND-SF36 total, mental and physical) and in headache severity according to the hormonal profile of the tumor also showed no significant results (Table 3).

The HIT- 6 values, and thus the headache severity, was inversely correlated to the quality of life assessed by total RAND SF36 ( $r=-0.516 ; \mathrm{p}=0.008)$, including its mental $(\mathrm{r}=-0.547 ; \mathrm{p}=0.005)$ and physical dimensions $(\mathrm{r}=-0.473$; $\mathrm{p}=0.01)$.

\section{DISCUSSION}

There are other published series of patients that had its ISP monitored ${ }^{4,7-16}$. The difficulty with this subject is,

Table 3. Headache severity measured by the HIT-6 score and quality of life evaluated by the total RAND SF36 and its mental and physical dimensions, according to the hormonal profile of the tumor.

\begin{tabular}{lccc}
\hline & & \multicolumn{3}{c}{ Type of tumor (n) } \\
\cline { 2 - 4 } Variable $(\mathrm{n})$ & $\begin{array}{c}\text { Cushing's disease (5) } \\
\text { mean } \pm \text { SD (range) }\end{array}$ & $\begin{array}{c}\text { Acromegaly (4) } \\
\text { mean } \pm \text { SD (range) }\end{array}$ & $\begin{array}{c}\text { Non-secreting (16) } \\
\text { mean } \pm \text { SD (range) }\end{array}$ \\
\hline Total RAND SF36 & $37 \pm 18(19-64)$ & $48 \pm 31.9(16-91)$ & $59 \pm 17.8(33-89)$ \\
Mental RAND SF36 & $32 \pm 16.4(11-55)$ & $45 \pm 38.1(12-88)$ & $60 \pm 16.3(26-86)$ \\
Physical RAND SF36 & $37 \pm 16.9(17-61)$ & $46 \pm 32.3(15-91)$ & $57 \pm 18.1(34-89)$ \\
HIT-6 & $58 \pm 12.5(44-72)$ & $55 \pm 18.5(36-75)$ & $57 \pm 11.4(36-70)$ \\
\hline RAND SF-36: Research and Development Short Form Health Survey:SD·Standard Deviation:HIT-6: Headache Impact Test.
\end{tabular}


among other factors, the lack of an appropriate animal model and the need for surgical indication due to pathology in the sellar region. The intervention in healthy patient with the aim of measuring the pressure would be ethically reprehensible and highly questionable, considering the current evidence from literature.

The ISP values obtained in different studies have varied. The first 24 published values were in patients that showed an average of $25 \mathrm{mmHg}^{7}$. In the largest series, an ISP average of $20 \mathrm{mmHg}$, ranging from 11 to $30 \mathrm{mmHg}$, was found ${ }^{9}$. Yet, the first work using fiberoptic catheter (which is technically simpler and does not require repositioning and injection of a solution to ensure the patency of the system) showed mean ISP value of $28.8 \mathrm{mmHg}$. In the present series, an average value of $33.3 \pm 12.1 \mathrm{mmHg}$ was found, which is higher than those previously published.

To our knowledge, up to the present moment this is the only study in which the HIT-6 assessment scale was used to define the presence and severity of headache in patients with intrasellar adenoma. This scale has been applied in 2537 primary medical care patients with various pathologies ${ }^{17}$. A distribution according to the class of pain of $6 \%$ mild, $14 \%$ moderate, $14 \%$ substantial and $66 \%$ intense was observed. The prevalence of any type of headache in the general population is considered as $80 \%{ }^{19}$ and in patients with pituitary adenoma it is $69 \%{ }^{16}$. Considering it as frequent complaint, it would be possible to suppose that there were no differences between headache in patients with pituitary adenomas and within the general population.

Some features, however, could define subpopulations of patients with adenoma where headache was more important. In 64 patients, macroadenomas (diameter $\geq 10$ $\mathrm{mm}$ ) were more associated to the presence of headache ${ }^{16}$. In another analysis involving ISP, $56.6 \%$ of 30 patients with adenoma had headache. In these, the pressure was higher $(19.2 \pm 9.8$ against $15 \pm 9.2 \mathrm{mmHg})$ and so was the volume $\left(18.3 \pm 32.3 \text { against } 5.2 \pm 6.1 \mathrm{~cm}^{3}\right)^{13}$. In the present study, such findings could not be confirmed. That could be because stratification by the severity of headache reduces the number of individuals in subgroups and, hence, limits the analysis. The sizes of the tumor were evaluated as micro and macroadenomas and by extent of the area, but not by volume. On the other hand, and in accordance with our finding of no correlation between ISP and headache severity through HIT-6, there are other factors that may be more important than ISP in headache genesis. Cavernous sinus invasion by the pituitary adenoma has already been described as a condition associated with the presence of headache ${ }^{16}$. In our series, six patients had such finding, and the mean HIT-6 value for these cases was 64.5 , against 56.7 for the others. The presence of headache in patients with microadenoma, with intact sella and no cavernous invasion, addresses to the likely involvement of inflammatory or hormonal factors of local action ${ }^{20}$.

Headache, characteristic or not of patients with pituitary adenomas, has substantial impact on quality of life. The World Health Organization defines quality of life as "the individual's perception of his position in life, in the context of culture and system of values in which he lives and in relation to his goals, expectations, standards and concerns". This concept is complex and emphasizes parameters that are wider than the control of symptoms, reduction in the mortality rate or increase in life expectan$\mathrm{cy}^{21}$. The use of standardized instruments to assess functional status and well-being dates back over 300 years ${ }^{18}$. The SF-36 is an abbreviated questionnaire resulting from RAND (Research and Development Corporation) health batteries based on a multidimensional definition of health and created for the Health Insurance Experiment and later for the Medical Outcomes Study ${ }^{18}$. An Italian study including 150 patients with headache showed a total and subgroup score at the SF-36 scale well below Italian general population ${ }^{22}$. The relationship between headache severity and the level of quality of life was also confirmed by this study, once the total RAND SF-36 measurement, and also its mental and physical dimensions, had inverse correlations of moderate and significant intensities with the HIT-6 values. This is probably due to the impact of pain on the daily life and limitations in individual capabilities.

The quality of life may vary according to the endocrine function of the tumor. In 168 patients with pituitary adenomas, it was noted that patients with acromegaly had scores that were lower in the physical than in the mental dimension. However, patients with Cushing's disease showed lower-than-average scores compared to the control population. The same authors found a RAND SF-36 average of less than 50 for the group of non-secreting tumors. Patients with Cushing's disease seem to have the worst quality of life, compared with other types of tumors $^{23}$. In this series, both in the total assessment and in the mental and physical dimensions, patients with Cushing's disease also presented the worst quality of life, followed by acromegaly (Table 3), according to the RAND SF-36. It is worth mentioning that the procedure for calculating each dimension results from the average of five different scales, from the eight present in the questionnaire, with superposition of measures of general health and vitality ${ }^{24}$.

In $40 \%$ of our patients, no visual field changes were observed and there was no significant relationship between ISP and the number of affected quadrants $(\mathrm{p}=0.137)$. Nevertheless, campimetry may be altered by other diseases, such as glaucoma. This might have explained visual field changes in two patients with microadenoma. 
The prevalence of visual field changes in pituitary adenomas has been variable throughout history. In 200 consecutive patients, only $9 \%$ of visual field defects could be found ${ }^{25}$. The authors of that report also reviewed four series (total of 1307 patients) and examined the presence of visual field changes in patients with pituitary adenomas. The prevalence of this association ranged from 31 to $86 \%$. In another study, 93 patients with non-secreting pituitary adenomas were examined ${ }^{26}$. Eighty-eight patients (94.6\%) had visual field deficits. In $74.2 \%$ of the times, changes were typical (bitemporal hemianopsia). All patients with lesions larger than $2 \mathrm{~cm}^{2}$ had visual changes, and the severity was proportional to the tumor volume. Gondim ${ }^{13}$ found $36.7 \%$ of visual changes in 30 patients and associat$\mathrm{ed}^{16}$ the displacement of the chiasm to headache, and the ISP for the group with visual deficits $(19.0 \mathrm{mmHg})$ was similar to the group without the deficit $(18.1 \mathrm{mmHg})$. It is reasonable to believe that the increase in intrasellar pressure produces a force vector directed to the least resistant regions, in this case, the upper portion of the sella, near the diaphragm. This alteration would injure the optic chiasm $^{15}$. However, the increased pressure does not occur steadily with the increase in volume, since it is highly dependable on sellar integrity ${ }^{14}$. If any sellar limit is ruptured, increased intrasellar mass volume is no longer necessarily raising the ISP. Individual factors such as volume and local inflammatory reaction may have similar or greater impact in determining visual loss, as well as headache $^{20}$, and may be object of future researches. The concomitant assessment of quality of life would also be as important to analyze the full extent of these and other conditions in individuals with pituitary adenoma.

In conclusion, the mean ISP measured was $33.3 \pm 12.1$ $\mathrm{mmHg}$. There was no correlation between ISP values and the number of visual quadrant affected. There was no correlation between the ISP values and the tumor area. There was no correlation between the ISP values and the scores on the total RAND SF-36 scale and with its physical and mental dimensions. There was no correlation between the ISP values and the scores obtained through the HIT-6 scale. The headache severity measured by the HIT- 6 scale showed moderate and inverse correlation with quality of life, i.e., with total, mental and physical values of the RAND SF36 scale.

\section{REFERENCES}

1. Yamada S. Epidemiology of pituitary tumors. In: Thapar K, Kovacs K, Scheithauer BW, Lloyd RV (Eds). Diagnosis and management of pituitary tumors. New Jersey: Humana Press 2001:57-70.
2. Gorczyca W, Hardy J. Arterial supply of the human anterior pituitary gland. Neurosurgery 1987;20:369-378.

3. Arafah BA, Nekl KE, Gold RS, Selman WR. Dynamics of prolactin secretion in patients with hypopituitarism and pituitary macroadenomas. J Clin Endocrinol Metab 1995;80:3507-3512.

4. Arafah BA, Prunty D, Ybarra J, Hlavin ML, Selman WR. The dominant role of increased intrasellar pressure in the pathogenesis of hypopituitarism, hyperprolactinemia and headaches in patients with pituitary adenomas. J Clin Endocrinol Metab 2000;85:1789-1793.

5. Abe T, Matsumoto K, Kuwazawa J, Toyoda I, Sasaki K. Headache associated with pituitary adenomas. Headache 1998:38:782-786.

6. Baird A, Sullivan T, Zafar S, Rock J. Quality of life in patients with pituitary tumors: a preliminary study. Qual Manag Health Care 2003;12:97-105.

7. Lees PD, Pickard JD. Hyperprolactinemia, intrasellar pituitary tissue pressure and the pituitary stalk compression syndrome. J Neurosurg 1987;67:192-196.

8. Lees PD. Intrasellar pressure. Acta Neurochir (Wien) 1990;47(Suppl):S68-S70.

9. Lees PD, Fahlbusch R, Zrinzo A, Pickard JD. Intrasellar pituitary tissue pressure, tumor size and endocrine status: an international comparison in 107 patients. Br J Neurosurg 1994;8:313-318.

10. Kruse A, Astrup J, Cold GE, Hansen HH. Pressure and blood flow in the pituitary adenomas measured during transsphenoidal surgery. Br J Neurosurg 1992;6:333-341

11. Kruse A, Astrup J, Gyldensted C, Cold GE. Hyperprolactinemia in patients with pituitary adenomas. The pituitary stalk compression syndrome. $\mathrm{Br} J$ Neurosurg 1995;9:453-457.

12. Zayour DH, Selman WR, Arafah BM. Extreme elevation of intrasellar pressure in patients with pituitary tumor apoplexy: relation to pituitary function. J Clin Endocrinol Metab 2004;89:5649-5654.

13. Gondim JA. Pressão intra-selar nos tumores da hipófise. Estudo da relação: pressão intra-selar versus função hipotalâmica-hipofisária. Dissertação, Universidade Federal de São Paulo. São Paulo, 2004.

14. Gondim JA, Tella Jr OI, Schops M. Intrasellar pressure and tumor volume in pituitary tumor: relation study. Arq Neuropsiquiatr 2006;64:971-975.

15. Pereira-Neto A. Pressão intra-selar média, cefaléia, qualidade de vida e prolactina sérica: estudo prospectivo em 25 pacientes operados consecutivamente no hospital universitário de Brasília. Tese, Universidade de Brasília. Brasília (DF):2006.

16. Gondim JA, Almeida JP, Albuquerque LA, Schops M, Gomes E, Ferraz T. Headache associated with pituitary tumors. J Headache Pain 2009;10:15-20.

17. Nachit-Ouinekh F, Dartigues JF, Henry P, et al. Use of the headache impact test (HIT-6) in general practice: relationship with quality of life and severity. Eur J Neurol 2005;12:189-193.

18. Meneses RF, Ribeiro JP, Silva AM. Revisão da literatura sobre avaliação da qualidade de vida (QDV) de adultos com epilepsia: II. Facilidades na abordagem do tema. Psicologia, Saúde Doenças 2002;3:119-139.

19. Dahlöf CGH. Measuring disability and quality of life in migraine. Drugs Today (Barc) 2003;39(Suppl D):S17-S23.

20. Borba AM. Relação entre função hipofisária, síndrome metabólica e pressão intra-selar média em pacientes com adenoma de hipófise. Dissertação, Universidade de Brasília. Brasília (DF), 2008.

21. Yeng LT, Teixeira MJ, Romano MA, Greve JMD, Kaziyama HHS. Avaliação funcional do doente com dor crônica. Rev Med (São Paulo) 2001;(ed. esp. pt. 1): 443-473.

22. Bussone G, Usai S, Grazzi L, Rigamonti A, Solari A, D'Amico D. Disability and quality of life in different primary headaches. Results from italian studies. Neurol Sci 2004;25(Suppl 3):S105-S107.

23. Johnson MD, Woodburn CJ, Vance ML. Quality of life in patients with pituitary adenoma. Pituitary 2003;6:81-87.

24. Kalantar-Zadeh K, Kopple JD, Block G, Humphreys MH. Association among SF36 quality of life measures and nutrition, hospitalization, and mortality in hemodialysis. J Am Soc Nephrol 2001;12:2797-2806.

25. Anderson D, Faber P, Marcovitz S, Hardy J, Lorenzetti D. Pituitary tumors and the ophtalmologist. Ophthalmology 1983;90:1265-1270.

26. Shenoy TR, Seshadri MS, Muliyil J, Rao A, Paul P. Visual defects in non-functioning pituitary adenomas. Indian J Ophthalmol 2002;50:127-130. 